\title{
The Value and Services of Urban Stream Polygnotou, Thessaloniki ${ }^{\dagger}$
}

\author{
Eleni A. Athanasiadou ${ }^{1, *}$, Maria Tratsela ${ }^{2}$ and Eleni Gkrimpa ${ }^{2}$ \\ 1 School of Agriculture, Faculty of Agriculture, Forestry and the Natural Environment, Aristotle University \\ of Thessaloniki, University Campus, P.O. Box 281, 54124 Thessaloniki, Greece \\ 2 School of Architecture, Faculty of Engineering, AUTh, University Campus, 54124 Thessaloniki, Greece; \\ mtrats@arch.auth.gr (M.T.); elenigkrimpa@gmail.com (E.G.) \\ * Correspondence: lenovio@agro.auth.gr; Tel.: +30-2310-998645 \\ + Presented at the 3rd EWaS International Conference on "Insights on the Water-Energy-Food Nexus", \\ Lefkada Island, Greece, 27-30 June 2018.
}

Published: 10 September 2018

\begin{abstract}
Grey, blue and green infrastructure supports socio-ecological processes the city undergoes. Yet, procedures of constructing anthropogenic habitats often undermine the value of natural landscape elements such as urban streams. Thessaloniki's backbone comprises of urban streams that run from the suburban forest of 'Seih-Sou' to the Thermaikos Gulf acting as corridors of the natural urban matrix. Policies of the past have dealt with urban streams through extensive engineering drainage methods, eliminating the risk of flooding, yet resulting in rapid stormwater runoff, water quality problems, disturbed riparian ecosystems, leading to the urban stream syndrome. Furthermore, they have failed to address urban streams as an inseparable part of the landscape and thus to incorporate them in people's mental map and everyday activities. The paper discusses the case of 'Polygnotou stream' which forms the beginning of the large scale engineered peripheral moat of Thessaloniki, constructed in the $60^{\prime} \mathrm{s}$, and playing the role of the water recipient for six urban streams in total. It falls unknown to the majority of people living in the area, yet its services as an ecosystem ought to be acknowledged, helping inform decision makers of its socioecologic, perceptual and economic value. In addition, Polygnotou stream, adjacent streams and the peripheral moat overall, could be considered as a touristic product of great importance.
\end{abstract}

Keywords: streams; urban streams; landscape architecture; Polygnotou stream of Thessaloniki; peripheral moat of Thessaloniki; water in landscapes; water landscapes; Thessaloniki

\section{Introduction}

A city is a constructed landscape which epitomizes human intelligence and creativity, depicts social, cultural and economic development and still remains the most favorable and important habitat for the human species [1]. Urban wetlands, such as streams and rivers are infrastructural landscapes. The hydrological and stormwater system underlying the Emerald necklace of Boston, designed by landscape architects in 1878-1896, indicates the ability of urban wetlands to act structurally and ecologically as vessels and pathways of water, if only design does not alter entirely their physical characteristics which has happened in many cases in the most recent years. This approach of dealing with urban wetlands, depictures in them a view of nature as the 'villain', the 'threat' that needs to be controlled [2]. Furthermore, Mossop, (2006) [3] suggests that 'if we see landscape as an infrastructure which underlies other urban systems, rather than simply equating with nature or ecology, we have a much more workable conceptual framework for designing urban systems'. In addition, we have a more interdisciplinary, unified field, the landscape, for design and ecology orientated principles to work together. 
Policies of the past have dealt with urban streams and rivers unilaterally, simplifying their management only in providing flood protection. The majority of streams in Thessaloniki have been extensively marginalized, excluded from any chance of connection to the citizens and the majority of them ended up as concrete channels of none or very limited ecological and social value. There is a recent global rejuvenation of the idea of urban streams acting as vessels of social life, and this provides opportunities for their protection and improved management.

\section{Ecology, Services and Values of Streams}

Stream ecology studies mainly involve research on (a) stream biota organisms, (b) the physical characteristics of streams (flow, light, temperature, dissolved oxygen, $\mathrm{pH}$ ) and the interrelation of the two [4]. Acquiring knowledge on stream ecology basics ought to be a perquisite for planners, engineers and landscape architects. Another thing that one is to consider is that flowing waters provide important goods and services which humans depend on.

Stream ecosystem services:

(1) provide a unique natural anti-flooding mechanism, since they are the arteries and irrigation system of the earth.

(2) create habitats and thus support many species of flora and fauna, including humans.

(3) support educational purposes and act as an alive laboratory for obtaining knowledge on biodiversity, anti-erosion techniques etc.

(4) improve of the microclimate, reduction temperature and the urban heat island effect.

(5) reduce of pollution and noise via stream vegetation [5].

(6) Furthermore, stream ecosystems provide potable water, connect with the global cycles (water, carbon, etc.), transport water and sediments, C, N from land to sea. Finally, they are 'alive' infrastructure and provide aesthetic enjoyment and spiritual renewal.

\section{Restoration and Social Integration of Streams in the Urban Fabric}

The term "urban stream syndrome" describes the consistently observed ecological degradation of streams [6] Ecologists have described the urban stream syndrome with elevated levels of nutrients and contaminants, increased hydrologic flashiness, and altered biotic assemblages [7]. According to the European Center of River Restoration (ECRR) [8]: 'river restoration refers to a large variety of ecological, physical, spatial and management measures and practices. These are aimed at restoring the natural state and functioning of the river system in support of biodiversity, recreation, flood management and landscape development'. Yet, throughout the globe, 'traditional' management of urban streams and rivers includes a highly 'tamed', controlled river in the form of a concretized channel with hardened banks. Flow control with the creation of dams and diversions highly alter mechanisms and processes of the riparian system. Examples include the Huangpu River in Shanghai, the river Nile in Egypt, Cairo etc. This humanly engineering solution provides potable water and water for agricultural purposes, yet eliminates almost entirely riverine ecosystem ecological functions. The Los Angeles river, running from Santa Suzana Mountain, is a typical example of practices of the past. It comprises of a concrete channel built by the U.S. Corporation of Engineers in response to serious flood threat posed by the snow melting in spring, combined with surface runoff from surrounding environments. Landscape architects, ecologists, biologists, environmentalists and most importantly citizens and community groups express their will for 'restoration', for converting the concrete channel into a living blue-green corridor. Numerous recent examples of urban stream and river restoration indicate the need for inclusion of these elements in the urban fabric and in everyday life of citizens. Not to mention a few (Seira, 2017) [9]: Obispo, Saint Louis USA (1999), Cheonggyecheon, Seoul, South Korea (2005), Sanlihe, Qian'an, China (2010-2012), Rippowam, Standford, USA (2012-2013), Deichgärten and Donaupark, Deggendorf, Germany (2009-2014), Aire, Geneva, Switzerland (2002-2015), Bottière Chênaie project, France (2008-2015), Isar river, Munich, Germany (2000-2011), Eleorema Toumpas (2017), etc. 
Patten (2016) [10] describes three stream/river restoration examples, (a) the Colorado River/Glen Canyon Dam [11], (b) Owens River and Mono Basin and (c) Phoenix, Arizona (which receives water from the Colorado River). The above cases "involve decisions for riverine sustainability after citizen concern that include dam operations and controlled water releases for down-stream riverine restoration, and water management aside from dam operations for irrigation, urban use and riverine restoration". Patten states that "all cases have a decision stage that determines how an altered or highly modified natural ecosystem will continue to produce ecosystem goods and services, that help maintain sustainability of the receiving urban ecosystem, while guiding attempts at sustainability of the natural ecosystem".

Many of efforts of fluvial systems restoration appear to be "research" in nature and the outcomes are often evaluated under the concept of 'adaptive management'. Adaptive management also known as adaptive resource management (ARM) or adaptive environmental assessment and management (AEAM) is a structured, iterative process of robust decision making in the face of uncertainty, with an aim to reducing uncertainty over time via system monitoring. Fluvial ecosystems are highly unpredictable, seasonably changing, self-regulated systems and adaptive management, that is 'learning from doing' is applied in many cases. The concept of adaptive management is not new to large scale design of landscapes; landscapes develop over time and new proposals for large scale areas such as Fresh Kills in New York and Downsview Park in Toronto are launched with this mentality printed across the master plans. System monitoring is a common practice among stream ecologists; spatio-temporal analysis helps creating ecological profiles and public preference spots and habits. Research and monitoring information along with the acknowledgement of the values of local citizens and guidance from experienced river scientists have produced approaches to restoring the Lower Owens River, the largest ongoing river restoration project of its kind ever undertaken in the United States, initiated in 2006 [12].

The greatest challenge facing those who study stream ecosystems and which is even more imperative to those challenged with the design of such ecosystems, is the reconciliation between the needs of humanity and those of the organism stream [13]. The success of river ecosystem maintenance and/or restoration is based not only on science but also on human values and public contributions [10]. In the long term, this dichotomy between nature and city, this exclusion of man from his first home, nature, the absence of knowledge and collection of experiencing nature has created a gap, a perplexity on how humans deal with streams and other natural elements on their endeavor of designing cities [14]. This relationship must be reclaimed. If ecology is the study of the relationships between organisms and their environment, certainly the relationship between man and urban streams is something to be re-examined.

\section{The Urban Stream Polygnotou}

Thessaloniki used to be a city of streams. Many researchers have studied the streams of Thessaloniki [15-21] and it has also been the study of academic courses. For over 20 years, the theme of the project given to students of architecture for the academic course 'Landscape Architecture, open space design', School of Architecture, Aristotle University of Thessaloniki, was a design for the streams of Thessaloniki, either Polygnotou, or Konstantinidi and others. Instructors Mary Ananiadou-Tzimopoulou, Maria Tratsela and other (Figure 1).

The peripheral moat of Thessaloniki (Figure 2) is an engineered concrete channel serving as a flood protection mechanism for the eastern part of the city. The moat 'blocks' stream access to the sea as it cuts cross- sectionally, the east city. It crosses four municipalities, Thessaloniki, Triandria, Pilea end Kalamaria, having a total length of $8 \mathrm{~km}$, a slope between $1 \%$ and $8 \%$ and the lowest point of its surface is at $25 \mathrm{~m}$ above sea level. The construction was complete by 1960, and with a surface area of $4.7 \mathrm{~km}^{2}$, it collects and drains $80 \%$ of resulting waters of the natural drainage basins of eastern Thessaloniki. The moat is able to drain the waters from a total area of $36.6 \mathrm{~km}^{2}$. During the fifty years between 1896 and 1956 rapid rainfalls have been recorded. On the 3rd of November of 1937 the heaviest rainfall has been recorded $(68 \mathrm{~mm}$, one hour and $10 \mathrm{~min})$. The moat has been designed on the basis of this rapid physical phenomenon that statistically takes place every fifty years. It is the 
main rainwater draining channel of the city since it receives the flows of four streams: (a) Konstantinidi, (b) Polygnotou, (c) Kyverneion, and its bifurcations Malakopi and Eleorema and (d) Allatini, [20].

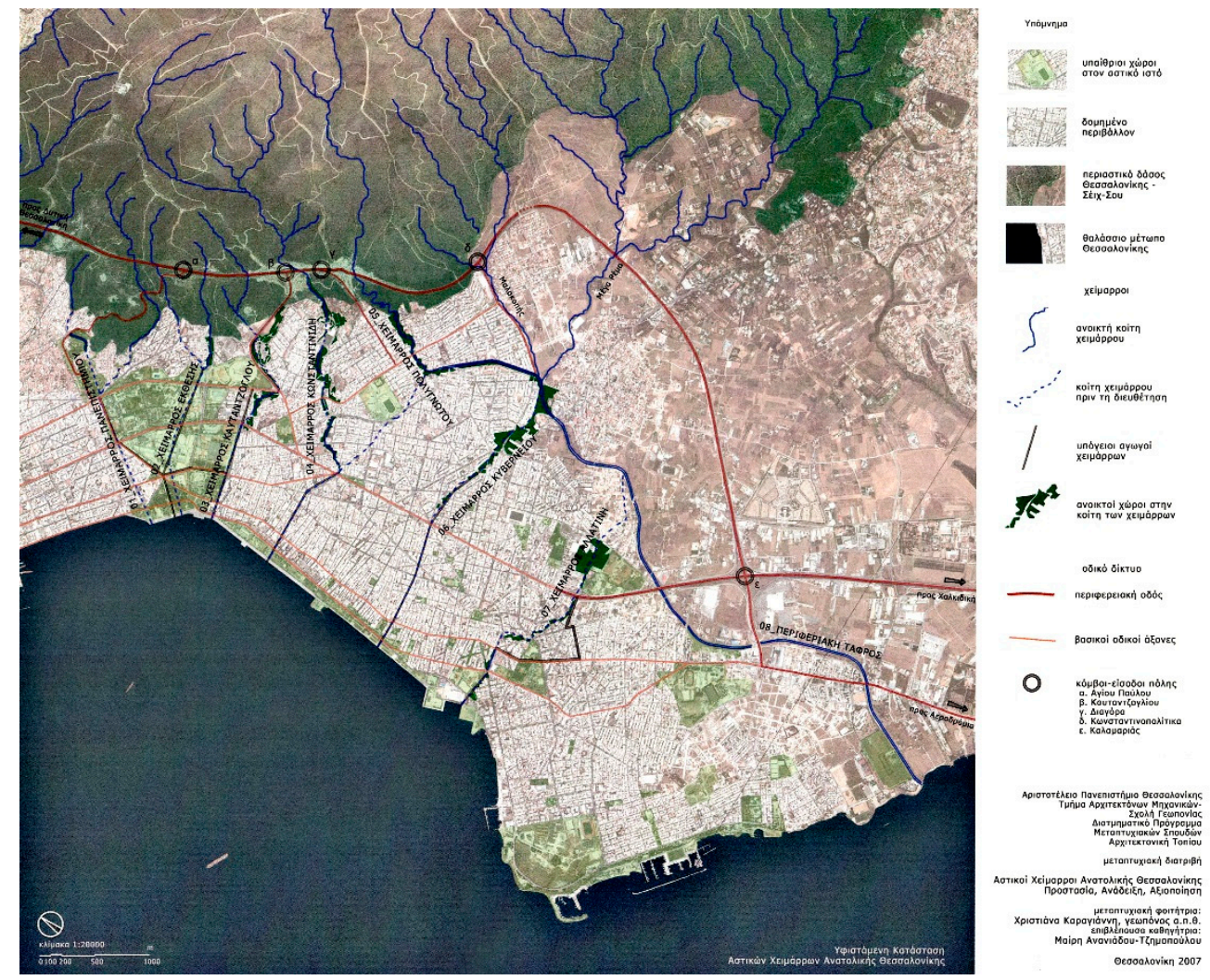

Figure 1. Urban streams of eastern Thessaloniki (In Greek) From left to right: Streams, 'Panepistimiou', 'Ekthesi', 'Kaftanzoglou', 'Konstantinidi', 'Polygnotou', 'Kiverneiou', 'Allatini'. Starting as Polygnotou Stream and ending up all the way to the sea as the Peripheral moat of Thessaloniki. Source: Karagianni, C.; 2007.

The stream of Polygnotou (or 'Lakos Profiti Elia'), is the starting point of the peripheral moat. It begins from the suburban forest of Seih-Sou, to meet 'Toumpa's Stream' under Labraki Str. 'Toumpa's Stream' then merges with 'Eleorema' to become the peripheral moat (Figure 3).

Polygnotou's stream boundaries comprise of (a) from the north, the only, downstream to the peripheral road, part of the suburban forest of Seih-Sou, (b) the Municipal cemeteries of Malakopi to the north-east, (c) Parmenidou str. and Pausania str. from the east and (d) Polygnotou str. from the west. It's a natural infrastructural landscape of $3.5 \mathrm{kh}$ and one of the few, if not the only, stream in the urban fabric with an intact, almost completely natural bed. To the North, it connects with the forest of Seih-Sou under the peripheral motorway to meet forest recreation infrastructure. To the south, it crosses Labraki Str. underneath to be renamed/join Toumpa's Stream. The value of urban stream Polygnotou lays basically to the fact of its degree of naturalization, indicating healthy ecological processes, yet evident is the urban stream syndrome due to eroded banks and invasive ground cover vegetation. Based on (a) physical parameters alternations such as vegetation, slope, access, degree of naturalization and (b) conceptual characteristics alternations such as 'openness/closeness' and shape, colour, texture and form of landscape elements, the stream can be divided in three (c) conceptual landscape units: (a) the forest-like ecosystem to the north, (Unit I) (b) the open gorge type landscape with ground cover vegetation to the middle, upstream to the Labraki Str. (Unit II) and (c) the channelized bank within a flat meadow-like landscape downstream the Labraki Str. (Unit III) (Figures 3 and 4). 


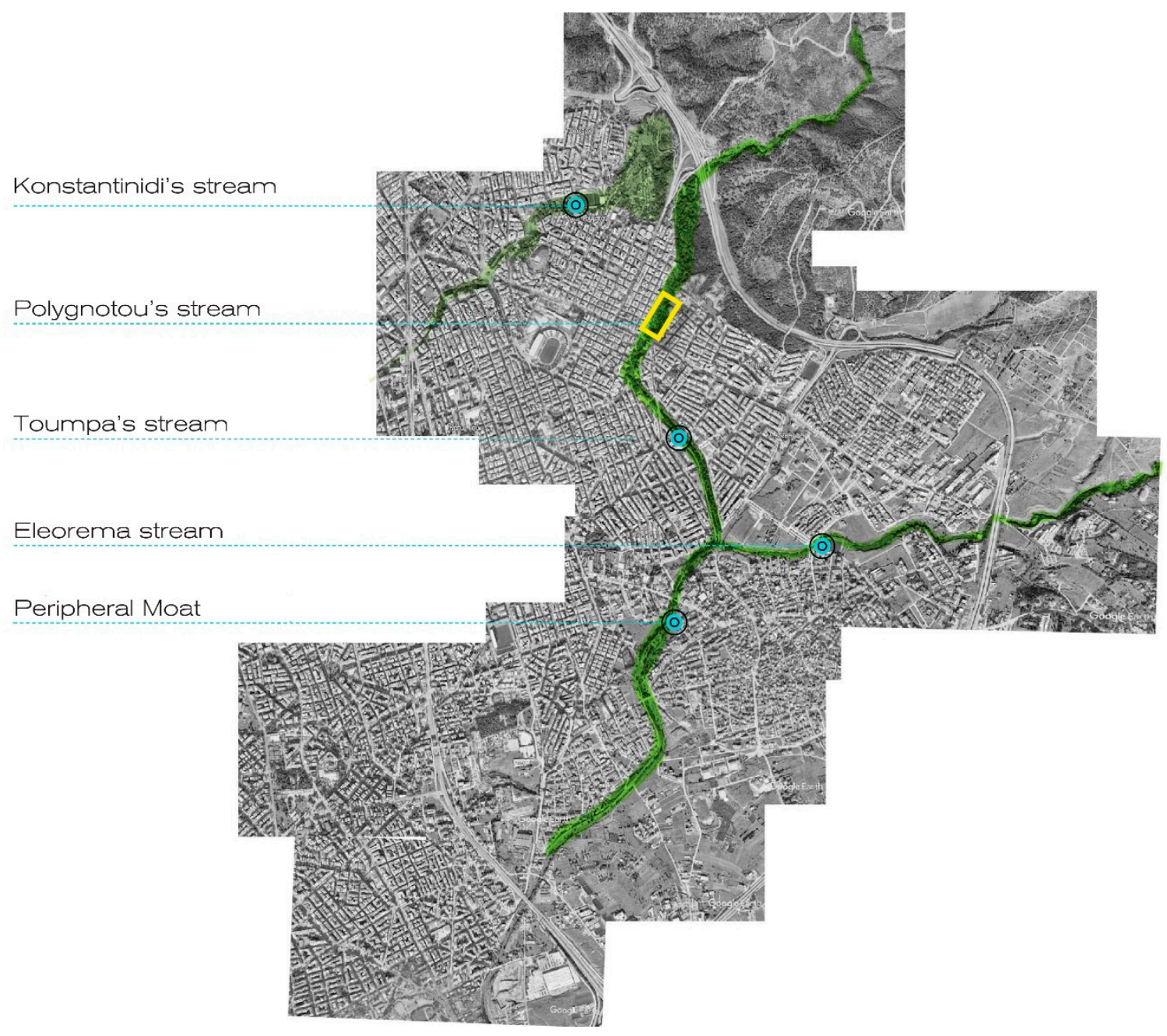

Figure 2. Streams and the peripheral moat at eastern Thessaloniki. Source: [21].

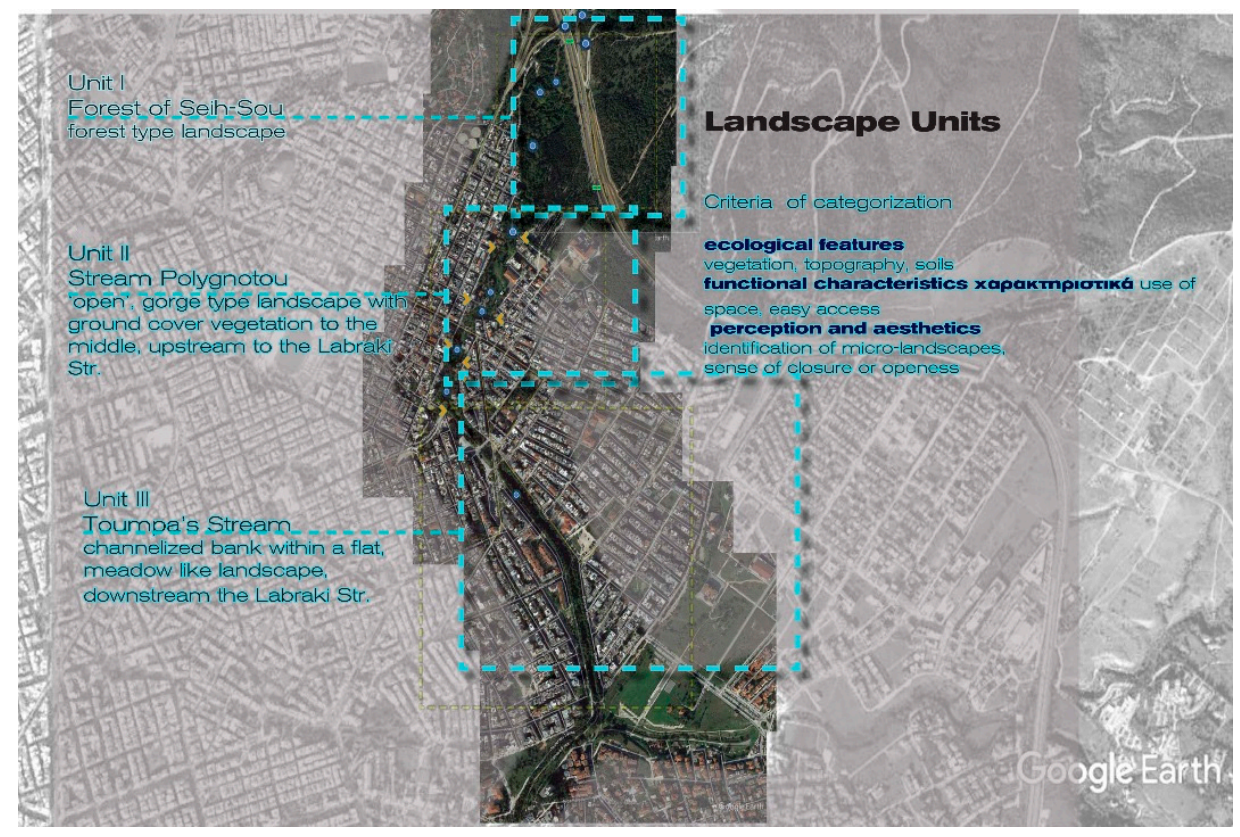

Figure 3. Stream Poygnotou and landscape units Source: [21]. 


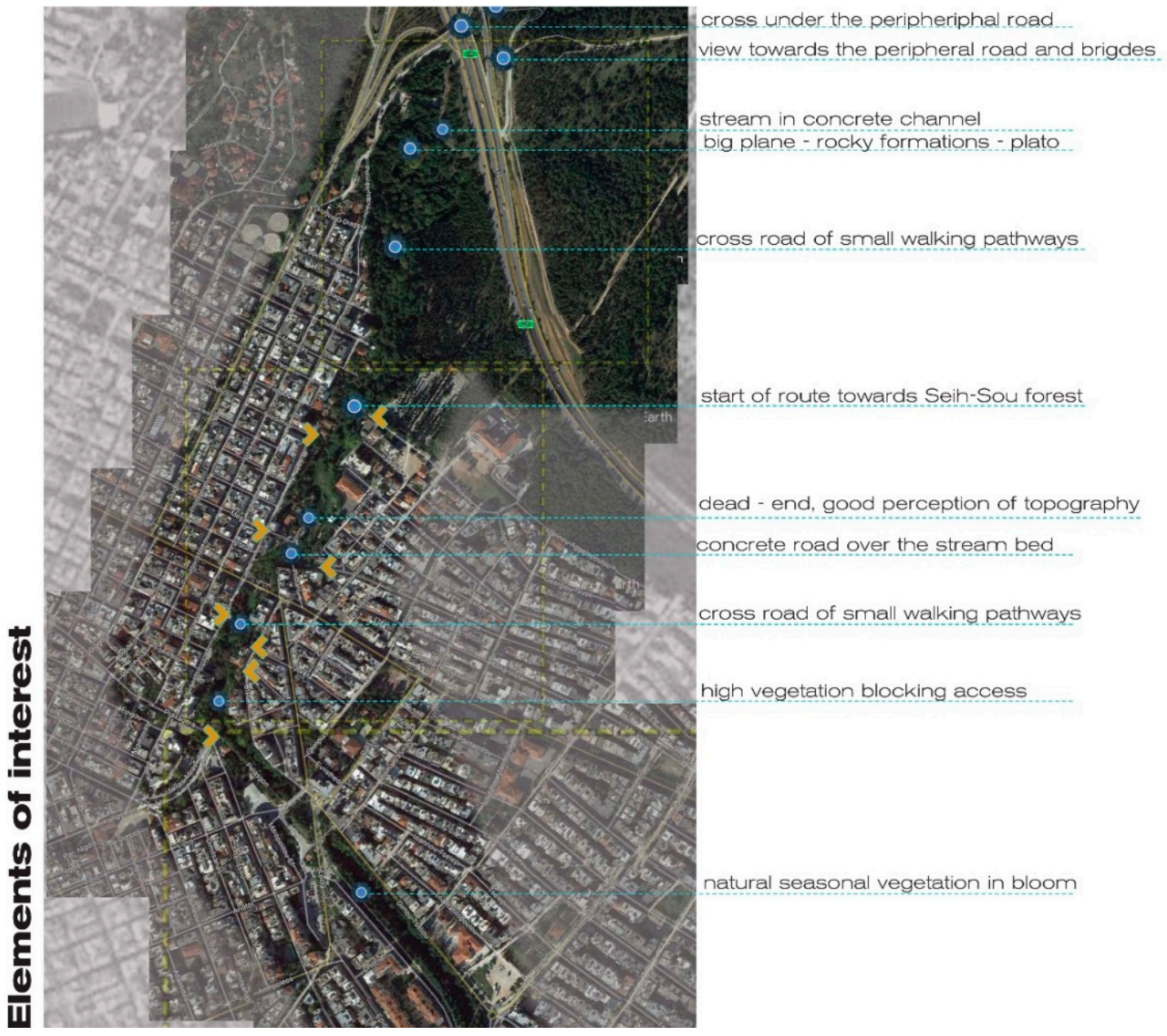

Figure 4. Stream Polygnotou, Points of interest. Source: [21].

The stream's ecological, perceptual and social value has not been studied systematically, neither has its role as a touristic landscape. Yet numerous points of interest underline its potential (Figure 5a-c). Unit II especially, which access is limited via extensive shrubbery vegetation and illegal housing on both sides of the banks, seems completely detached from the everyday life of citizens, despite the fact that on its north-east side, adjacent to the municipality cemeteries, 77th elementary and 23rd kindergarten school of Thessaloniki are active. Yet, the variety of shrubs, trees and ground cover, the alternations in its topography and the shear fact of its untamed nature, provide in close proximity to the urban fabric a potential cultural node. The stream's services as a natural irrigation system are evident in days of heavy precipitation, yet this ability is negatively influenced by the debris people dump in it. Urban stream Polygnotou is a part of a bigger fluvial ecosystem, which starts from the Seih-Sou forest to meet the peripheral moat of Thessaloniki and 'Eleorema' and to diffuse all the way to a semi-natural delta by the sea, adjacent to the National School of Judges in Thessaloniki. Toumpa's stream meets the peripheral moat and the later ends to the old ceramic factory Allatini. From Polygnotou to where the peripheral moat meets the national road of Thessaloniki-Moudanion is only a $5 \mathrm{kh}$ one-way walk. Yet people prefer walking not on Polygnotou stream but at Toumpa's Stream, Eleorema and the Peripheral moat due to improved access. 


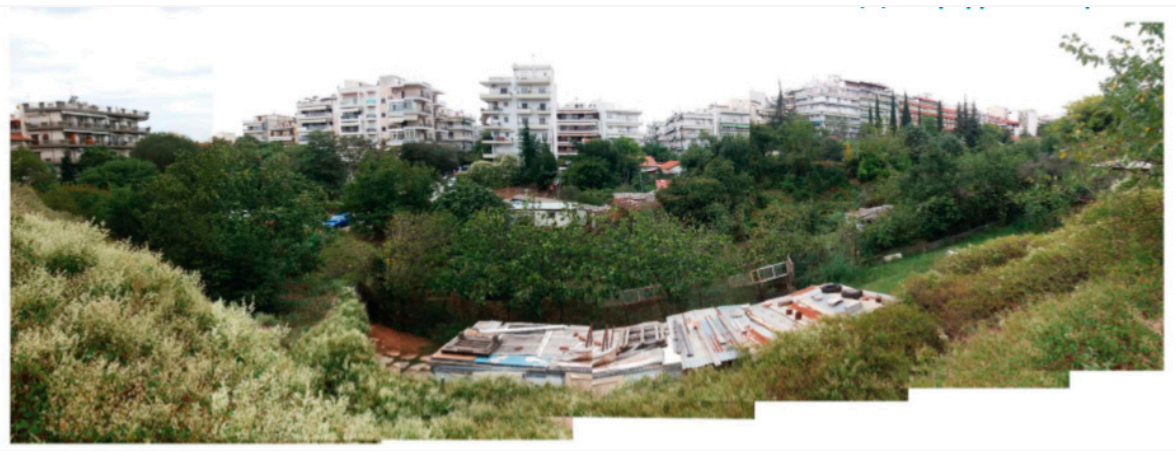

(a)

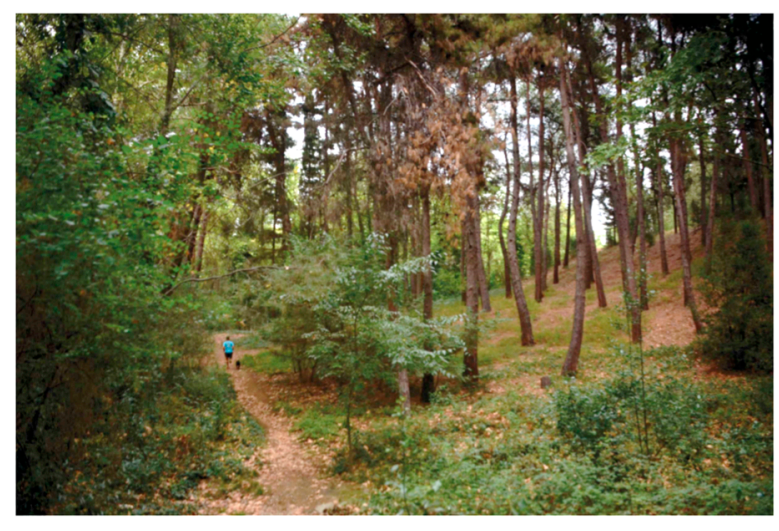

(b)

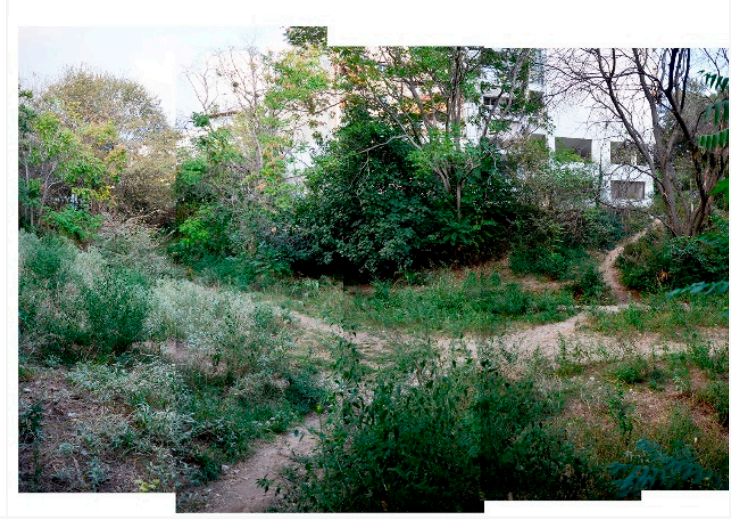

(c)

Figure 5. (a-c) Stream Polygnotou. Landscape Units: top, Unit II open gorge type landscape, bottom-left, Unit I the forest-like ecosystem and bottom-right, the channelized bank within a flat meadow-like landscape.

\section{Conclusions}

The understanding of urban fluvial ecosystems and their protection depends not only in scientific advances, quantification studies and ecological knowledge. It involves conceptualizing them as infrastructural landscapes capable of being part of everyday life and re-connecting them to the urban tissue. Due to anti-flooding policies of the past, the urban streams of Thessaloniki have been disconnected from the urban fabric and from people's consciousness. Even up to date practices in many cases deal with them merely as hazardous landscapes which ought to be tamed, not involving social aspects in the design. Urban stream Polygnotou is an alive, natural specimen of cultural heritage. It is one of the only remaining streams in Thessaloniki with an intact bed and is part of a bigger water-recreation corridor, the peripheral moat of Thessaloniki.

Policies for its management ought to address (a) the preservation of its natural history, (b) its connectivity to the adjacent streams and the peripheral moat and (c) any bottom-up people's initiatives for use of the space.

The urban stream Polygnotou, has the potential of becoming part of a sustainable 'green' touristic vision. Its role in urban life ought to be reconsidered as a unique opportunity emerges for the formation a big blue-green infrastructural landscape, running from the suburban forest of SeihSou to Thermaikos bay.

\section{References}

1. Athanasiadou, E.A.; Tratsela, M. The role of monitoring spatio-temporal change in achieving resilience of the suburban landscape. In Urban Regions, Now and Tomorrow, Between Vulnerability, Resilience and Transformation, Studien Zur Resillienszforschung; Deppisch, S., Ed.; Springer: Wiesbaden, Germany, 2017; pp. 17-40.

2. Corner, J. Terra fluxus. In The Landscape Urbanism Reader; Waldheim, C., Ed.; Princeton Architectural Press: New York, NY, USA, 2005; pp. 21-33. 
3. Mossop, E. 2006. Landscapes of infrastructure; Terra Fluxus. In The Landscape Urbanism Reader; Corner, J., Waldheim, C., Eds.; Princeton Architectural Press: New York, NY, USA, 2005; pp. 165-177.

4. Wright, K. Stream Ecology Basics. 2012. Available online: https:/www.youtube.com/ watch?v=9MnmlGOFewQ (accessed on 7 September 2018).

5. Karakinari, Z.; Tsiouris, S. The multiple role of urban natural torrents. In Proceedings of the Landscape Architecture, Education, Research and Practice, Joint Postgraduate Program Landscape Architecture AuTh, Polytechnic School AUTh, Thessaloníki, Greece, 11-14 May 2005; Volume IV, pp. 55-61.

6. Walsh, C.J.; Roy, A.H.; Feminella, J.W.; Cottingham, P.D.; Groffman, P.M.; Morgan, R.P. The urban stream syndrome: Current knowledge and the search for a cure. J. N. Am. Benthol. Soc. 2005, 24, 706-723. doi:10.1899/04-028.1.

7. Meyer, J.L.; Paul, M.J.; Taulbee, W.K. Stream ecosystem function in urbanizing landscapes. J. N. Am. Benthol. Soc. 2005, 24, 602-612. doi:10.1899/04-021.1.

8. The Network of Best Practices of River Restoration in Greater Europe, ECRR, European Center of River Restoration. Available online: http://www.ecrr.org/RiverRestoration/Whatisriverrestoration/tabid/2614/ Default.aspx (accessed last time on 7/9/2018).

9. Seira, E. Landscape Architecture of Urban Streams. 'Dendropotamos', the River of Northwest Thessaloniki. MLA Dissertation Thesis, Joint Postgraduate Program of Studies in Landscape Architecture, AUTh, Thessaloníki, Greece, 2017. (In Greek)

10. Patten, T.D. The role of ecological wisdom in managing for sustainable interdependent urban an natural ecosystems. Landsc. Urban Plan. 2106, 155, 3-10.

11. Lustgarten, A. Unplugging the Colorado River. Could the end be near for one of the West's biggest dams? The New York Times, 2016. Available online: https://www.nytimes.com/2016/05/22/opinion/unplugging-thecolorado-river.html (accessed last time on 7 September 2018).

12. Inyo County Water Department, The Lower Owens River Project. Available online: http://www.inyowater.org/ projects/lorp/ (accessed last time on 7 September 2018).

13. Allan, J.D.; Castillo, M.M. Stream Ecology. Structure and Function of Running Waters, 2nd ed.; Springer: Dordrecht, The Netherlands, 2017.

14. Tratsela, M.; Athanasiadou, E.; Tsalikidis, I.A. Landscape architecture and environmental protection: Contemporary planning approaches and issues. In Proceedings of the Protection and Restoration of the Environment XI, AUTh and Stevens Institute of Technology, Thessaloniki, Greece, 3-6 July 2012.

15. Karakinari, Z. Wetland Landscapes of the Western Coast of Thessaloniki. The Gallikos River Delta, the Lagoon of Kalochori, the Stream of Dendropotamos. A Landscape Architecture Study. Master's Thesis, Joint Postgraduate Program of Studies in Landscape Architecture, AUTh, Thessaloníki, Greece, 2005. (In Greek)

16. Karagianni C. Urban Streams of Eastern Thessaloniki. Protection-Highlighting-Exploitation. Master's Thesis, Joint Postgraduate Program of Studies in Landscape Architecture, AUTh, Thessaloníki, Greece, 2007. (In Greek)

17. Axarli, E. 2013. Criteria and Methodology for the Optimal Development of Urban Streams. Ph.D. Thesis, School of Civil Engineering, AUTh, Thessaloníki, Greece, 2007.

18. Tsoumalakos, S. Urban. Streams of Thessaloniki (Greece): Spatial and Hydraulic Aspects. Msc Thesis, Postgraduate Program in Protection of the Environment and Sustainable Development, School of Civil Engineering, AUTh, Thessaloníki, Greece, 2017. (In Greek)

19. Blionis, G.; Tremopoulos, M. Thessaloniki of Waters; A Historical and Ecological Anaskopisis of the Topography of Streams and Water Resources of the City; Antigoni Publishing: Thessaloniki, Greece, 2017. (In Greek)

20. Chatziagorou, E. Technical Anti-Flooding Works in the Urban Open Space and in Landscape Architecture. The Case of the Peripheral Moat of Thessaloniki. Measures for Protection, Management and Design. MLA Thesis, Joint Postgraduate Program of Studies in Landscape Architecture, AUTh, Thessaloníki, Greece. (In Greek)

21. Athanasiadou. Unpublished Notes for the Undergraduate Course, 07EE10 Landscape Design of Urban Open Spaces, School of Architecture, Aristotle University of Thessaloniki, 2017.

(C) 2018 by the authors. Licensee MDPI, Basel, Switzerland. This article is an open access article distributed under the terms and conditions of the Creative Commons Attribution (CC BY) license (http://creativecommons.org/licenses/by/4.0/). 